\title{
Paweł Wolski \\ Antyczna filozofia i poezja: zły glina, dobry glina
}

\author{
k $\quad r \quad y \quad t \quad y \quad k \quad$ i : \\ $\mathrm{Malcolm} \mathrm{Health,} \mathrm{Interpreting}$ \\ Classical Texts, Londyn 2002 .
}

Poetyka klasyczna to dziedzina o bogatych tradycjach. Uprawia ją wielu znakomitych badaczy, których głos rzadko daje się jednak usłyszeć poza utwierdzonymi tą tradycją granicami klasycznej filologii. Owszem, czerpią z niej obficie supergwiazdy akademii, których nazwiska znane są i poza nią: Heidegger, Derrida, de Man itp., są to jednak, by tak rzec, raczej inspiracje poetyką antyczną, luźne i przykrojone (często w sposób ahistoryczny) do współczesności egzegezy wybranych pojęć z zakresu starożytnej kultury (np. eidolon u Heideggera czy pharmakon u Derridy) niż filologiczne analizy.

Malcolm Heath bez wątpienia nie należy do tego grona - nie jest autorem „używającym” klasycznej poetyki po to, by tworzyć teorie (współczesnego) tekstu. Nie jest też jednak badaczem odsyłającym takie próby w przestrzeń niegodnej klasycznego filologa dezynwoltury. Heath bowiem, jak można sądzić po quasi-autobiograficznym wstępie do Interpreting Classical Texts, stara się umieścić swoje wnikliwe rozważania gdzieś pomiędzy tymi biegunami:
Kiedy w roku 1980 zaczynałem pisać doktorat o greckiej tragedii, byłem przekonany, że będę musiał poświęcić sporo czasu i wysitku na wypracowanie właściwej metodologii. To dość dziwne przekonanie (bo w owym czasie na oksfordzkim wydziale studiów klasycznych niewiele uwagi poświęcało się teorii literatury) przywiodło mnie do wniosku, że musze stworzyć system, który będzie respektował autorskie intencje (ale nie tak, jak u Hirscha), uwzględni teorię recepcji (ale nie jak u Jaussa), będzie osadzony w kontekście obejmującym różnorodne projekty teoretyczne w sposób krytyczny i pluralistyczny (ale nie synkretyczny) i podszyty będzie perspektywą hermeneutyczną (ale nie jak u Gadamera) oraz pragmatystyczną (ale nie jak u Rorty'ego), a przy tym będzie cechował się takim podejściem do języka, dla którego de Saussure nie będzie jedynie słusznym punktem wyjścia, co skazałoby mnie na konieczność poigrywania z jego zdekonstruowanymi szczątkami . 
Ze słów tych wyziera pragnienie mówienia o antycznej poetyce w sposób, który oddali się od hermetycznych egzegez filologów, ale nie zbliży też za bardzo do anachronizującej tę poetykę teorii współczesnej. Wobec tej drugiej Heath jest, jak widać, nieufny, ale nie całkiem wrogi (może poza ledwo hamowaną niechęcią do dekonstrukcji). W efekcie zarówno cytowana przed chwila książka, jak i większa część pisarstwa Heatha to próba wyabstrahowania z antycznej tradycji wątków pozwalających zrozumieć jej wpływ na naszą współczesność, podejmowana jednak w sposób, jaki nie uchybiłby jej macierzystemu kontekstowi.

Jedna z najnowszych jego książek, Ancient philosophical poetics², ukazała się w serii „Key Themes in Ancient Philosophy”, która w zamierzeniach wydawców „będzie prezentować zwarte wywody na temat tych zagadnień starożytnej filozofii, które są aktualne także dla filozofii współczesnej, napisane przez najważniejszych badaczy w tej dziedzinie, zrozumiałe dla nieprofesjonalistów"3. Program Heatha wpisuje się więc doskonale w tak sformułowane wydawnicze credo. I rzeczywiście, dokonując wnikliwej analizy pism Platona, Arystotelesa, Epikura, Maksymosa z Tyru, Plotyna, Longinusa i innych, Heath stara się pokazać czytelnikowi logikę wywodu starożytnych na temat tego, czym jest poezja/literatura, ale nie wychodzac przy tym poza horyzont filozofii antycznej (czyli będzie „wrażliwa na teorię recepcji, ale nie jak u Jaussa"). W książce Heatha nie znajdziemy więc, mimo założeń serii (szukać „tych zagadnień starożytnej filozofii, które są aktualne także dla filozofii współczesnej"), ani jednej wzmianki o teoriopoznawczych wątkach greckiej filozofii w dzisiejszej teorii literatury - choć książka obfituje w momenty, w których takie skojarzenia się wręcz narzucają. Trudno, na przykład, nie myśleć o formalistycznych kategoriach „fabuły” i „sjużetu” (i ich Derridiańskich refutacjach), gdy autor wyjaśnia zawiłości zbyt często upraszczanego pojęcia jedności akcji u Arystotelesa („Początek następuje właściwie po wydarzeniach, ale nie musi koniecznie wynikać z czegokolwiek"^). Odwołanie się do nich bez wątpienia

\footnotetext{
2 Tegoż, Ancient Philosophical Poetics, Cambridge 2013.

3 Tamże, s. i.

4 Tamże, s. 85.
}

uprościłoby następujący potem kilkunastostronicowy wywód oparty na pojęciu prawdopodobieństwa w przyrodzie, ludzkiej wolności wyboru (phrohairesis) itp., ale, po pierwsze, nie spełniałoby ważnego założenia serii „Key Themes in Ancient Philosophy”, jakim jest pisanie dla „nieprofesjonalistów”, a po drugie, anachronizowałoby dyskurs Heatha. W konsekwencji w jego wywodzie nie tylko brak więc często zdarzających się w takim kontekście odwołań do dzisiejszej teorii (choćby w formie przypisowej: „dziś pojęcia te nazywamy...” itp.), ale wręcz niewiele w nim nawet metafor zaczerpniętych z czasów nam bliższych (a książka ma tło propedeutyczne - jakżeż łatwo z tej perspektywy byłoby np. wyjaśnić Platońską jaskinię za pomocą zjawiska telewizji lub wirtualnej rzeczywistości).

Autor czyni na samym początku następujące zastrzeżenie:

Jest to książka mówiąca o starożytnej poetyce w filozofii. Nie zajmuje się więc starożytną teorią literatury, krytyką literacką czy w ogóle badaniami nad literaturą. Są to sprawy bardzo interesujące i istotne dla naszego rozumienia starożytnej poezji. Ale w tym miejscu mamy zamiar objaśnić jedynie filozoficzne próby podjęcia zasadniczych problemów poezji ${ }^{5}$.

W praktyce wynika z tego, że Heath rzeczywiście opowiada raczej o tym, dlaczego Platon (albo Sokrates, w imieniu którego Platon pisze) uważał poetów za jedną z najniższych kast idealnego państwa („Oczywiście stoją niżej od filozofów, ale i niżej od legalnie obranych monarchów i wodzów; niżej od polityków, gospodarzy domu i biznesmenów; od trenerów sportowych i lekarzy, od wieszczów i kapłanów. Plasują się zaledwie odrobinę ponad rzemieślnikami i rolnikami, sofistami, demagogami; oraz tyranami”) lub jak poglądy Arystotelesa, w odróżnieniu od Platońskich/Sokratejskich, wynikają z jego inklinacji badacza przyrody („Platońska taksonomia sposobów prowadzenia narracji stanowiła statyczną mapę tego, co poecie dostępne; Arystotelejska

\footnotetext{
5 Tamże, s. 1.

${ }^{6}$ Tamże, s. 143
} 
rekonfiguracja jest dynamiczna. Natura poezji, będącej jednym ze zjawisk przyrody, ukazuje się tu jako zjawisko w pełni swego rozwoju"7), nie proponuje zaś metodycznego wykładu na temat koncepcji „dzieła literackiego” u któregokolwiek z nich. I choć po drodze czytelnik pozna podstawowe pojęcia poetyki fundujące ich poglądy na poezję, to akcent tych rozważań ostatecznie pada raczej na ontologię sztuki jako narzędzia epistemologicznego, czy też tego, jak jawi się ona w oczach filozofów (choć w kontekście analitycznego wywodu na temat nawet najtrudniejszych wątków filozoficznych dziwić może dość szczegółowe wyjaśnianie np. wspomnianej Platońskiej jaskini ${ }^{8}$, Sokratejskiej majeutyki ${ }^{9}$ itp. obrazów należących do wiedzy powszechnej; wynika to pewnie ze wspomnianego dydaktycznego wymiaru publikacji). A skoro książka rozpoczyna się od Platona, to, rzecz jasna, poezja oglądana przez pryzmat tej filozofii musi znaleźć się w pozycji oskarżonego.

Platon, jak wiadomo, wygnał poetów z doskonałego państwa, ponieważ ich moc czynienia zła powabnym, skłonność do czynienia bogów kłótliwymi, czy wreszcie skłonność do pokazywania trudów jeszcze trudniejszymi, a śmieszności jeszcze śmieszniejszą, może demoralizować młodzież, która powinna kształcić się w cnocie, a nie w występkach, kłótniach lub czczej wesołości. Państwu potrzebni są przede wszystkim strażnicy i filozofowie; to ci ostatni będą, miast poetów, objaśniać młodzieży życie, bo to raczej ich mądrość, a nie próżność artystów, zapewnia dobrą o nim wiedzę. Na czym jednak polega ta wiedza? Jeśli na powtarzaniu szlachetnych wzorów, komentuje Heath ${ }^{10}$, to wystarczyłoby przecież zabronić tylko pewnej części poezji (w tym Homeryckich eposów, które bez kłótliwych bogów, stanowiących motor intrygi, przecież by nie istniały), a pozostawić poezję szlachetną, propagującą dobre wzorce. Platon (lub Sokrates), zauważa Heath, rzeczywiście wskazuje na taką możliwość (oszczędzenia kilku

\footnotetext{
7 Tamże, s. 82 [podkr. P.W.]. Patrz też s. 94-95 o różnicy poglądów Platona i Arystotelesa na stosowność komedii, wynikającej stąd, że drugi z nich widział w niej naturalną moc łagodzenia psychologicznych napięć.

8 Tamże, s. 31.

9 Tamże, s. 142.

${ }^{10}$ Tamże, s. 44 i n.
}

„właściwych” poetów); nie na tym jednak polega rehabilitacja poezji, która, jak twierdzi, jest jednak możliwa na gruncie pism Platona i platoników. Sprawa zasadza się bowiem nie na samej imitacji, czyli umiejętności pięknego przedstawiania tego, co nie jest piękne, ale na prawdzie:

Jako że naśladuje się zewnętrzny wygląd, żeby stworzyć imitację, nie trzeba wcale rozumieć (a nawet mieć jakąś opinię o tym), czym co to coś jest. Dlatego też można naśladować tak wiele zjawisk. Bo jeśli naśladowanie wymagałoby rozumienia, naśladowcy musieliby być specjalistami we wszystkim. Naśladowca wszechstronny musi być więc naśladowcą nierozumnym ${ }^{11}$.

Poeci mogą więc ukazywać prawdę i dobro, ale ostatecznie często nie wiedzą, czym dobro i prawda są. Nie tylko więc nie dostrzegają tych wartości we własnych pieśniach, ale mogą błądzić, nie wiedząc przecież, czego szukają. To dlatego potrzeba państwu filozofów - to im zależy, by szukać dobra (a nie poklasku, jak poeci), a wręcz tylko oni to potrafią. Jednak to znów nie wszystko, ciągnie Heath. Jeśli czytać Platona w możliwie najszerszym kontekście, co oznacza także: przez pryzmat późniejszych platoników, wówczas jego/Sokratesa zarzuty wobec np. Homera są tak naprawdę zastrzeżeniami wobec jego roszczeń do poznania prawdy. Te roszczenia zaś są, co prawda, nieuzasadnione filozoficznie, ale mieszczą się w pełni w koncepcji poezji (i, w pewnym sensie, wiedzy) jako boskiej mocy. Wieszcz i poeta mają, mówiąc krótko, prawo mówić o rzeczach, których nie rozumieją, a ich niezrozumienie wcale nie będzie przeczyć tych rzeczy prawdzie. Sokrates, jak dowodzi Heath, wcale nie był absolutnie wrogi wieszczom. Zarzut platoników (a więc pewnie i w jakiejś mierze także Platona i Sokratesa) wobec Homera można więc sprowadzić właściwie do tego, że podobnie jak wieszcz, poeta mówi prawdę, ale, po pierwsze i już wspomniane, nie rozumiejąc jej, a po drugie, robi to w sposób zawiły:

Platon często bierze na warsztat to, co mówią poeci, po to, żeby obnażyć nieskuteczność poezji

\footnotetext{
${ }^{11}$ Tamże, s. 45.
} 
jako źródła wiedzy. Na przykład Polemarch cytuje Symonidesa w pierwszej księdze Państwa, ale kiedy Sokrates go sprawdza, okazuje się, że albo jest to cytat błędny, albo jest to jakaś typowa zagadka stworzona przez poetę (1, 332b-c: zob. §2.2). [...] Zdaniem Sokratesa wynika to stąd, że poeci mówią zagadkami. Kłopot z poezją, która czasem sprawia wrażenie mylnej albo niejasnej, polega na tym, że nie możemy spytać zmarłych poetów o to, co mieli na myśli albo dojść do porozumienia w sprawie znaczenia ich poezji między sobą (Prt. 347e; Hi.Min. $365 c-d)^{12}$

Znaczenie, o którym mowa w ostatnim zdaniu, nie jest jednak znaczeniem sensotwórczym i teleologicznym w rozumieniu celowego wytwarzania jakiejś jakości. Aby wyjaśnić, czym jest, Heath angażuje Arystotelesa, stanowiącego w strukturze książki jakby rozjemcę między Platonem, wrogim poetom (jak już wiemy: pozornie, a w każdym razie niefundamentalnie), otwierającym książkę i zamykającymi ją kontynuatorami jego myśli (rzeczywiście, jak przyznaje Heath, traktującymi dość wybiórczo myśl intelektualnego mistrza ${ }^{13}$ i w związku z tym w sposób o wiele mniej zniuansowany wyklinający artystów słowa ${ }^{14}$ ). Arystoteles - którego Heath przedstawia jako projektującego swoje doświadczenie biologa na poglądy na poetykę - doskonale ukazuje, w czym poezja zbliża się do filozofii; choć i u niego jest to forma mniej wartościowa, to obie po prostu szukają piękna i dobra dla samego dobra i piękna: „Słuchanie dobrej muzyki albo oglądanie tragedii lub sportu to wprawdzie rzeczy mniej wartościowe niż filozofia, ale same w sobie jednak jakoś wartościowe”15. Fuzja tego stanowiska z poglądami Platona i platoników znacząco zmienia krytykę Homera (i innych poetów, jednak to właśnie Homer jest głównym oskarżonym); teraz zarzuty wobec niego sprowadzają się do tego, że aby pojąć prawdę jego pieśni, należy włożyć w ich pojmowanie ogromny wysiłek interpretacyjny, taki jak przy interpretacji delfickiej wyroczni:

\footnotetext{
12 Tamże, s. 143.

${ }^{13}$ Tamże, s. 137.

${ }^{14}$ Tamże, s. 104 i n.

${ }^{15}$ Tamże, s. 103.
}

Stawiając nas przed szokującą prawdą o Homerze jako o [nierozumiejącym - P.W.] naśladowcy, Platon pragnie sprawić, byśmy sami wyzbyli się powierzchownego podejścia do jego poezji, które uniemożliwia nam dotarcie do kryjącej się w niej głębszej prawdy $^{16}$.

\section{$[\ldots]$}

Założeniem kryjącym się za tak usilnym konfrontowaniem nas z szokującymi implikacjami powierzchownej lektury Homera jest szokowanie nas naszą własną powierzchownością. Powinniśmy wyciągnąć z niej wniosek, że poezja ta wyraża głębokie prawdy filozoficzne w sposób symboliczny. Nie musi to wcale znaczyć, że Homer te prawdy zgłębił albo objaśnił lub mógł uzasadnić, gdyby Sokrates zaczął go o nie rozpytywać. Chodzi o to, że prawdy te przyszły do niego z zewnątrz, za pośrednictwem boskiego natchnienia - jak to zresztą Platon mówił już gdzie indziej ${ }^{17}$.

Z tak widzianego porządku wywodu Heatha (zaprezentowanego tu w ogromnym uproszczeniu), wyciągam taki oto wniosek: używając języka niemal do zera minimalizującego niebezpieczeństwo kontaminacji filozoficznego świata pojęć sprzed wielu tysięcy lat, udało się badaczowi ukazać zaskakująco współczesnych filozofów-poetów i poetów-filozofów. Pierwszym efektem rozumiejącego czytania ówczesnych pochwał i (częściej) potępień poezji przez filozofów jest oczywiście to, że jawią się teraz oni jako współcześni teoretycy literatury, którzy wyraźnie lub ukrycie głoszą, że bez nich literatura stałaby się niezrozumiała (bo dziś przecież nawet tezy o końcach wielkich narracji - także teoretycznych - albo postulaty miłosnego, nieprzeteoretyzowanego obcowania z tekstem same stają się, jak wiadomo, wielkimi narracjami lub teoriami). Drugim, mniej oczywistym, jest jednak to, że skoro filozof staje się w ten sposób swoistym „poetą interpretacji”, to i poeta jawi się trochę jako filozof: jeśli Homer znał prawdę, tylko jej nie rozumiał, to nie błądził dlatego, że był poetą, ale dlatego, że był filozofem; tyle że złym.

\footnotetext{
${ }^{16}$ Tamże, s. 144.

${ }^{17}$ Tamże, s. 146.
} 
Jonathan Culler, broniąc pozycji literatury w czasach, gdy granice literackości przesunęły się tak dalece, że jej tożsamość stała się sprawą wątpliwą, pisał:

Być może literatura utraciła swą centralną pozycję jako specyficzny przedmiot badań, ale jej metody zwyciężyły: w naukach humanistycznych i społecznych wszystko jest literackie. Skoro literatura to, jak mawialiśmy, dyskurs świadomy swojej fikcjonalności, konsekwencją teorii było uświadomienie różnym dyscyplinom fikcjonalności i performatywności ich własnych konstrukcji, co świadczy na korzyść tezy Simpsona o sytuacji dyscyplin. Kiedy dyskursy różnych dyscyplin zajmują się problemem własnej pozycji, swoim usytuowaniem i konstrukcją własnych schematów, zajmują się literaturą ${ }^{18}$.

Heathowi udało się, jak starałem się pokazać, zrobić coś podobnego z pozycją poezji w nie zawsze łaskawej dla niej filozofii antycznej. I jakkolwiek siłą rzeczy wyjść musiał od układu odwrotnego: to znaczy od opinii, że „W naukach humanistycznych wszystko jest filozoficzne”, to $w$ jego rozprawie część tego filozoficznego powabu przypadła i poezji. A co przy tym ważne: dokonał tego nie uciekając się do pomocy nieufnie traktowanych w przywołanym na początku tekście Hirshów, Gadamerów, Jaussów, Rortych. Albo Cullerów. 


\title{
SEOWA KLUCZOWE:
}

\author{
filozofia antyczna \\ teoria literatury
}

poetyka

antyczna

\begin{abstract}
AbstrakT:
Autor omawia książkę Ancient philosophical poetics Malcolma Heatha, który stara się w niej przybliżyć czytelnikom zarówno akademickim, jak i spoza specjalistycznego kręgu poglądy filozofów na poezję. Czyniąc zastrzeżenie, że nie jest to rozprawa o tym, jak wyglądała teoria literatury w czasach starożytnej Grecji, ale o tym, jak filozofia spoglądała na poezję, Heath ukazuje poglądy filozofów na prawdę i dobro w poezji. Jakkolwiek najczęściej jest to pogląd o niższości poezji wobec filozofii (angielski badacz skupia się na filozofii Platona i platoników, choć także Arystotelesa), to autor Ancient philosophical poetics udowadnia ostatecznie, że np. słynne platońskie wezwanie do wygnania poetów z państwa jest w istocie wezwaniem do wnikliwego ich czytania. Autor omówienia jego książki ukazuje w związku z tym wywód Heatha jako przykład bardzo współczesnej, a jednocześnie nieanachronizującej postawy wobec antycznej filozofii i poetyki.
\end{abstract}

\section{NOTA O AUTORZE:}

Paweł Wolski - pracownik Zakładu Teorii i Antropologii Literatury Wydziału Filologicznego Uniwersytetu Szczecińskiego, absolwent Uniwersytetu Szczecińskiego i Universita' degli Studi di Genova, 2014 Fulbright Visiting Professor na Brandeis University (USA), współredaktor czasopism naukowych „Autobiografia” oraz „Narracje o Zagładzie”, kierownik Szkoły Języka i Kultury Polskiej dla Cudzoziemców. Publikował m.in. w „Tekstach Drugich”, „Storia della Storiografia”, „Pamiętniku Literackim”, „Porównaniach” oraz innych czasopismach polskich i zagranicznych. Autor przekładów z języka angielskiego, francuskiego, włoskiego i niemieckiego. 